\title{
Avena sterilis L. (wild oat) response to Clodinafop-propargyl in wheat crops in Morocco
}

\author{
Hajjaj B*, El Oualkadi A*
}

\author{
*Regional Agricultural Research Center of Tangier, Morocco \\ Corresponding author. E-mail: h_badr15@yahoo.fr
}

\begin{abstract}
Avena sterilis is problematic weed that affects wheat production. The aim of this study is to investigate the effect of Clodinafop-propargyl on A. sterilis infestation in a soft wheat crop. The experimental design was Randomized Complete Block Design (RCBD) with three replications. Each block contained 4 elementary plots, 3 plots of which were treated with three rates of application of Clodinafop-propargyl and one untreated control plot. Trial were conducted in Ouazzane region of Morocco in January 2018. Treatments were carried out with a knapsack sprayer with the nozzle delivering a 3 bar jet. A quadrant of $1 \mathrm{~m} x 1 \mathrm{~m}$ was used to calculate percentage of A. sterilis density reduction and biomass reduction. A. sterilis dry biomass were determined using an oven at $75^{\circ} \mathrm{C}$ for 48 hours. Then, weighed with a precision balance. Results showed that treatments with Clodinafoppropargyl at $60 \mathrm{~g} / \mathrm{ha}$ and $80 \mathrm{~g} / \mathrm{ha}$ gave the best control of A. sterilis infestations recording respectively $96.1 \%$ and $99.4 \%$ of A. sterilis density reduction and $98.2 \%$ and $99.7 \%$ of A. sterilis dry biomass reduction. Clodinafoppropargyl at $40 \mathrm{~g} / \mathrm{ha}$ recorded lower efficacies $75.3 \%$ and $80.1 \%$ respectively on A. sterilis density reduction, and A. sterilis dry biomass reduction.
\end{abstract}

Keywords-Avena sterilis, Clodinafop-propargyl, wheat, density, biomass.

\section{INTRODUCTION}

Weeds compete on water, minerals and sunlight and decrease wheat production in Morocco (Zimadahl \& El Brahli, 1992; Boutahar, 1994; Taleb, 1996; Bouhache, 2007; Bouhache, 2017). Avena sterilis L. (wild oat) belongs to Poaceae botanical Family. It is an annual plant. Upright $50 \mathrm{~cm}$ to $1.50 \mathrm{~m}$ high. Leaves with limbs usually hairy at its base and on the margin. Eroded-acute ligule. No auricles. Panics 30 to $50 \mathrm{~cm}$ long. Lower flowers covered with silky hairs and twisted dorsal edges (Tanji, 2005). Upper hairless flowers. Flowers stand out together at maturity. Equal glumes, 3 to $5 \mathrm{~cm}$, Spikelet with 3 to 5 flowers. Spread flower Spikelet forming an open V. Brown or black seeds, 2 to $3 \mathrm{~cm}$ long and 3 to $6 \mathrm{~mm}$ wide, 5 to $6 \mathrm{~cm}$ long (Tanji, 2005). Plant quite abundant throughout Morocco. It grows on different types of soil. It is consumed by animals. Infestations on cereal fields may led to refusal of the harvested product by Moroccan seed companies (Tanji, 2005). Clodinafop-propargyl is a systemic herbicide absorbed by leaves to control grasses. It belongs to the Aryloxyphenoxy-propionate 'FOPs' family. It causes inhibition of acetyl CoA carboxylase (ACCase) (Ezzahiri \& al., 2017). ACCase enzyme catalyzes the fatty-acid synthesis. This herbicide inhibit the ACCase enzyme activity, thus blocking the production of phospholipids necessary for synthesizing the lipid bilayer, which is indispensable for cell structure and function. Avena sterilis become is a serious problem in cereal fields in Ouazzan region of Morocco that causes reduction of cereal production. The aim of this study is to compare the effect of three doses of Clodinafop-propargyl on Avena sterilis infestation in a soft wheat crop in the Ouazzan region of Morocco.

\section{MATERIAL AND METHODS}

A weeding trial was conducted in Ouazzane region of Morocco during 2017-2018 growing season. The experimental design was Randomized Complete Block Design (RCBD) with three replications. The distance between the blocks was 2 meters and the distance between plots was 1 meter. Each block contained 4 elementary plots, 3 plots of which were treated with the post-emergence herbicides tested (Table 1) and one untreated control plot. The size of the elementary plots was $2 \mathrm{~m} \times 5 \mathrm{~m}\left(10 \mathrm{~m}^{2}\right)$. Treatments was carried out on January 2, 2018 with a Knapsack herbicide sprayer with nozzle delivering a 3 bar jet. The spray volume per hectare is 200L. Treatments consist on three rates of application of Clodinafoppropargyl (Table 1). Observations were at 60 days after application of herbicides. Observations concerned 
Percentage of $A$. sterilis density reduction and biomass reduction. A. sterilis density reduction percentage $=[A$. sterilis density in control plots $-A$. sterilis density in treated plots] X $100 /$ [A. sterilis density in control plots], Calculation of the density at the experimental level of the plot was made by a quadrant of $1 \mathrm{~m} \times 1 \mathrm{~m}$. A. sterilis dry biomass reduction percentage $=[A$. sterilis dry biomass weight in control plots $-A$. sterilis dry biomass weight in treated plots] $\mathrm{x} 100 /$ [A. sterilis dry biomass weight in control plots]. Calculation of dry A. sterilis biomass were made by collecting $A$. sterilis in each plot using a quadrant of $1 \mathrm{~m} \mathrm{x} 1 \mathrm{~m}$. Samples were dried in a drying oven at $75^{\circ} \mathrm{C}$ for 48 hours. Then, dry plant material in each plot were weighed with a precision balance. Statistical analyzes were performed with IBM SPSS Statistics, version 21.0 using the analysis of variance (ANOVA).The differences among treatment means was compared by Tukey's test at $P=0.05$.

Table 1: Applied herbicides in experimental site

\begin{tabular}{llc}
\hline $\begin{array}{l}\text { Herbicide } \\
\text { treatments }\end{array}$ & $\begin{array}{l}\text { Herbicide active } \\
\text { ingredient }\end{array}$ & $\begin{array}{l}\text { rate } \\
\text { application } \\
\text { (g/hectare) }\end{array}$ \\
\hline Treatment 1 & $\begin{array}{l}\text { Clodinafop- } \\
\text { propargyl }\end{array}$ & $40 \mathrm{~g} / \mathrm{ha}$ \\
\hline Treatment 2 & $\begin{array}{l}\text { Clodinafop- } \\
\text { propargyl }\end{array}$ & $60 \mathrm{~g} / \mathrm{ha}$ \\
\hline Treatment 3 & $\begin{array}{l}\text { Clodinafop- } \\
\text { propargyl }\end{array}$ & $80 \mathrm{~g} / \mathrm{ha}$ \\
\hline
\end{tabular}

\section{RESULTS AND DISCUSSION}

\section{Effect on $A$. sterilis density reduction}

Statistical analysis revealed significant differences between treatments (Table 2). Results in Table 2 showed that the best A. sterilis density reduction was obtained by Clodinafoppropargyl at $60 \mathrm{~g} / \mathrm{ha}$ and $80 \mathrm{~g} / \mathrm{ha}$ recording respectively $96.1 \%$ and $99.4 \%$ of $A$. sterilis density reduction. Clodinafop-propargyl at $40 \mathrm{~g} /$ ha showed lower efficacy $75.3 \%$ of A. sterilis density reduction (fig. 1).

Table 2: Effect of treatments on A. sterilis density reduction $(\%)$

\begin{tabular}{lc}
\hline Doses & $\begin{array}{c}\text { Avena sterilis } \\
\text { density reduction }\end{array}$ \\
\hline $\begin{array}{l}\text { Clodinafop- } \\
\text { propargyl at } 40 \mathrm{~g} / \mathrm{ha}\end{array}$ & $75.3^{\mathrm{a}}$ \\
\hline $\begin{array}{l}\text { Clodinafop- } \\
\text { propargyl at } 60 \mathrm{~g} / \mathrm{ha}\end{array}$ & $96.1^{\mathrm{b}}$ \\
\hline $\begin{array}{l}\text { Clodinafop- } \\
\text { propargyl at } 80 \mathrm{~g} / \mathrm{ha}\end{array}$ & $99.4^{\mathrm{b}}$ \\
\multicolumn{1}{c}{$P \alpha=0.05$} & $<0.001$
\end{tabular}

Significant differences within the same column and means followed by the same letter do not differ at $P=0.05$ according to Tukey's test

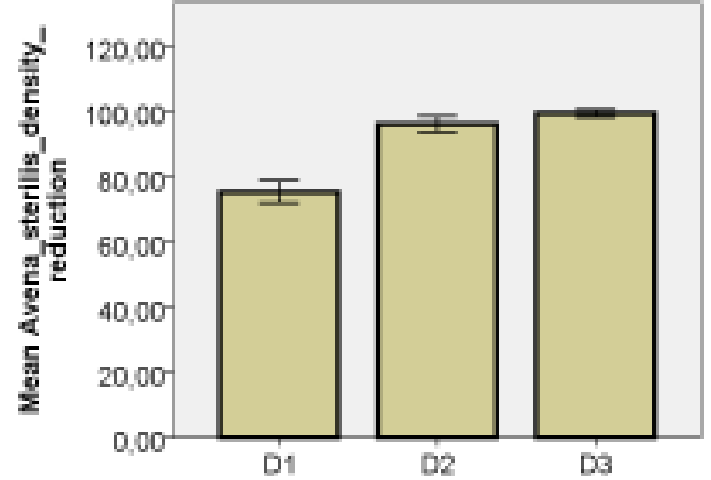

D1: Clodinafop-propargyl at $40 \mathrm{~g} / \mathrm{ha}$; D2: Clodinafoppropargyl at $60 \mathrm{~g} / \mathrm{ha}$; D3: Clodinafop-propargyl at $80 \mathrm{~g} / \mathrm{ha}$ Error Bars: $95 \% \mathrm{CI}$

Fig.1: Effect of treatments on A. sterilis density reduction (\%)

Table 3: Effect of treatments on A. sterilis dry biomass reduction (\%)

\begin{tabular}{ll}
\hline Doses & $\begin{array}{l}\text { Avena sterilis } \\
\text { density reduction }\end{array}$ \\
\hline $\begin{array}{l}\text { Clodinafop- } \\
\text { propargyl at } 40 \mathrm{~g} / \mathrm{ha}\end{array}$ & $80.1^{\mathrm{a}}$ \\
\hline $\begin{array}{l}\text { Clodinafop- } \\
\text { propargyl at } 60 \mathrm{~g} / \mathrm{ha}\end{array}$ & $98.2^{\mathrm{b}}$ \\
\hline $\begin{array}{l}\text { Clodinafop- } \\
\text { propargyl at } 80 \mathrm{~g} / \mathrm{ha}\end{array}$ & $99.7^{\mathrm{b}}$ \\
\hline \multicolumn{1}{c}{$P \alpha=0.05$} & $<0.001$ \\
\hline
\end{tabular}

Significant differences within the same column and means followed by the same letter do not differ at $P=0.05$

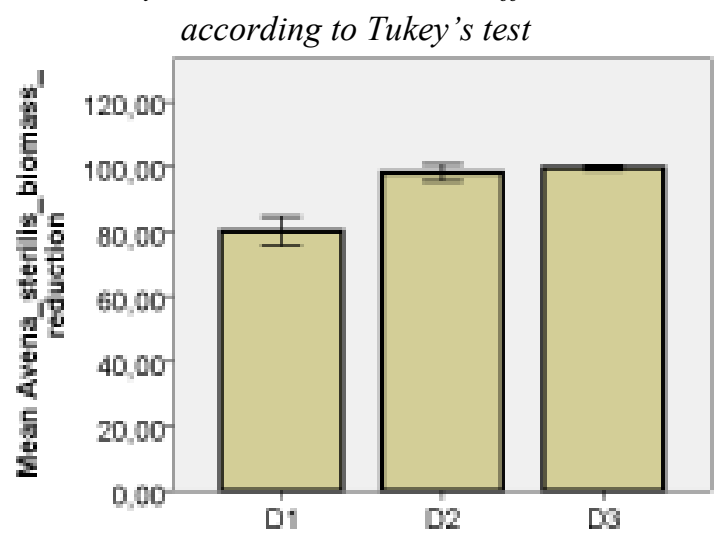

D1: Clodinafop-propargyl at $40 \mathrm{~g} / \mathrm{ha}$; D2: Clodinafoppropargyl at $60 \mathrm{~g} / \mathrm{ha}$; D3: Clodinafop-propargyl at $80 \mathrm{~g} / \mathrm{ha}$ Error Bars: $95 \%$ CI

Fig.2: Effect of treatments on A. sterilis dry biomass reduction (\%)

Effect on $A$. sterilis dry biomass reduction

Statistical analysis revealed significant differences between treatments (Table 3). Data in Table 3 indicate that the best A. sterilis dry biomass reduction was achieved by 
Clodinafop-propargyl at $60 \mathrm{~g} / \mathrm{ha}$ and $80 \mathrm{~g} / \mathrm{ha}$ recording respectively $98.2 \%$ and $99.7 \%$ of A. sterilis dry biomass reduction. Concerning the effect of Clodinafop-propargyl at $40 \mathrm{~g} / \mathrm{ha}$, results showed lower efficacy that did not exceed $80.1 \%$ of A. sterilis dry biomass reduction (fig. 2).

\section{CONCLUSION}

This study has shown that the herbicide Clodinafoppropargyl at $60 \mathrm{~g} / \mathrm{ha}$ and $80 \mathrm{~g} / \mathrm{ha}$ gave the best control of $A$. sterilis. Clodinafop-propargyl at $40 \mathrm{~g} / \mathrm{ha}$ lower control of $A$. sterilis. Thus, Clodinafop-propargyl at $60 \mathrm{~g} / \mathrm{ha}$ can be recommended to farmers in Ouazzane region when $A$. sterilis infestation is dominant. This study should be completed with the assessment of Clodinafop-propargyl effect on other problematic grasses.

\section{ACKNOWLEDGMENTS}

The authors are grateful to all technicians of ONCA Ouazzan for providing necessary facilities for conducting this research work.

\section{REFERENCES}

[1] Bouhache M. (2017). Chemical weed control in autumn sown cereals. Agriculture du Maghreb Num. 25: 57-62. French.

[2] Bouhache M. (2017). Strengths and weaknesses of herbicides used on cereals in Morocco. Agriculture du Maghreb Num. 100: 9-19. French

[3] Boutahar K. (1994). Impact of harvest date and presence of weeds on grain losses at harvest operation. Al Awamia Num. 85: 25-32. French.

[4] Ezzahiri B., Bouhache M., Mihi M. (2017). Phytosanitary index of Morocco. AMPP Maroc Editions. French.

[5] IBM SPSS Statistics for Windows, Version 21.0. (2012). Armonk, NY: IBM Corp.

[6] Taleb A. (1996). Weed flora of Morocco, Characterization and economic importance. Bulletin de transfert de technologie en agriculture Rabat Maroc, Num. 18. French.

[7] Tanji A. (2005). Weeds of wheat and barley in Morocco. INRA Editions, Rabat Morocco. French

[8] Zimadahl RL, El Brahli A. (1992). Losses caused by weeds on cereals in the semi-arid zone of western Morocco. Al Awamia Num. 75: 53-62. French 